\title{
J(e)
}

\begin{tabular}{||l||c||c||}
\hline \hline Received 17.07.2021 & & JOTS \\
& Review & $5 / 2$ \\
Accepted 23.07.2020 & & $2021: 434-439$ \\
\hline \hline Published 24.07.2021 & & \\
\hline
\end{tabular}

\section{Ağca, F. Dillik Ölçütlere Göre Eski Uygurca Metinlerin Tarihlendirilmesi, Ankara: Türk Dil Kurumu Yayınları, 2021, pp. 458, ISBN: 978-975-17-4822-5}

\author{
Buket Nur KIRMIZIGÜL ${ }^{*}$ \\ Eskişehir Osmangazi University (Eskişehir/Turkey) \\ E-mail: buketkirmizigul@gmail.com
}

Dillik Ölçütlere Göre Eski Uygurca Metinlerin Tarihlendirilmesi is a work that emerged as a book by Prof. Dr. Ferruh Ağca's PhD dissertation titled Eski Uygur Türkçesiyle Yazılmış Eserlerin Ses ve Şekil Özelliklerine Göre Tarihlendirilmesi, which he completed in 2006. The publication of this long-awaited study is now available to researchers in a more up-to-date and complete form, with the author's review.

Old Uyghur Turkish started to produce its first texts in the 8th century and became a written language in which this production continued until the 14th century. The writing date of the works in this language, which has been processed for more than six centuries, is mostly not certain. In addition, the language features of these works have changed over time. The number of texts of which writing or copying date is known by means of colophon records, is very few. Dating of other undated texts and division of Uyghur literature into periods, can be estimated according to language features of the texts, private person and place names in the texts, the location of the texts when they were found, the book format and the font types used.

However, there are some difficulties in dating the texts according to these features. First of all, since most of these texts are religious texts and aim to convey the teachings to the public, a work has been copied many times, has

\footnotetext{
ORCID ID: 0000-0003-0969-534X.
} 


\section{ग(৫)}

replaced many times by being moved from monastery to monastery. For this reason, it may be misleading to date the texts by considering their location. In addition, while the original texts reflect the language characteristics of the century they belong to, it is doubtful how much the copies made in later centuries reflect the language of their own century (Ağca, 2021: 63). A text may include the date it was copied on the colophon, but due to the tendency of religious texts not to distort the original, linguistic features may not resemble the date on the colophon but with features from a few centuries ago.

In addition to these, in a text that is understood to belong to the earliest stages of the Old Uighur language, may have features belonging to the very late periods or old and new structures can be seen together in some texts that are known to be of late date. These situations also create difficulties in dating texts according to language characteristics. Ağca considers these examples as the infiltration of the dialect features of the scribe into the standard language. He also considers the coexistence of old and new structures in late texts as archaism. According to Ağca, such language features deviating from the standard language cannot be used as a criterion in the chronological classification of texts (2021: $64)$.

Despite all these difficulties, Prof. Dr. Ferruh Ağca analysed an enormous corpus in great detail according to the 39 criteria which he determined, and gives a chronological order of Old Uyghur texts to the use of researchers. Another difficulty encountered while dealing with the changing language features of the texts is to determine which of them is due to dialect differences and which is due to the change of language in the historical process. It has been demonstrated that the language differences which were previously given by A. von Gabain as the Manichaean /n/ dialect or as the Buddhist /y/ dialect, do not differ sharply according to the religious environment to which the texts belong. The fact that some of the features claimed to belong to the Manichaean dialect are also present in the early Buddhist Uyghur texts and are not included in the later Manichaean Uyghur texts, shows that this actually stems from a historical change.

The dating of old Turkic texts on the basis of the colophon records and specific place and person names, previously studied by Gabain in Alttürkische 
Daiterungsformen (1955), by Bazin in Les systèmes chronologiques dans le monde turc ancien (1991) and by Zieme in Bemerkungen zur Daiterung uigurischer Blockdrucke (1981) and Religion und Geselschaft im Uigurischen Königreich von Qoço, Kolophone und Stifter (1992) (Ağca 2021: 69-70).

Another way of dating is to date the texts on the basis of linguistic criteria by following the changes and developments in the language features of the texts and by comparing the undated texts with the dated texts in this respect. Old Turkic texts were classified according to linguistic criteria for the first time in Erdal's article The Chronological Classification of Old Turkic Texts (1979) (Ağca 2021: 70). He basically divides the texts into four groups according to the 24 linguistic criteria, and besides these, there are two subgroups. In his work, he analyses the Köktürk and Yenisey inscriptions as well as the Uyghur texts according to the same criteria.

After Erdal, the other study in which old Turkic texts are systematically dated according to their language features belongs to Doerfer. First, in his article titled Bemerkungen zur chronologischen Klassifikation des älteren Türkischen, which he wrote in 1991, after briefly mentioning the criteria used in the classification and dating of old Turkic texts, he gave the century of the groups to which the texts belong. Doerfer, later reconsidered his views, expressed in this article, in his work Versuch einer linguistischen Daiterung älterer osttürkischer Texte (1993) (Ağca 2021: 72). He, within the framework of the 30 linguistic criteria, divided the old Turkic texts into five phases, and the first two phases each have four substages as 1a, 1b, 1c, 1d; 2a, 2b, 2c, 2d. According to this classification, the first phase includes the years about 750-948, the second phase covers the years 9901235, the third phase covers the year 1315, the fourth phase (except Altun Yaruq and Buyan Ävirmäk) 1313 and the fifth phase (except Insadi Sūtra) contains the date 1345. (Tekin, 1994: 186).

Since both studies by Erdal and Doerfer include Köktürk texts, some criteria used are only for distinguishing Turkish runic inscriptions and Old Uyghur texts and are not suitable for classifying and dating Old Uyghur texts in themselves. In Ağca's study, it is stated that care was taken to ensure that the criteria used in this work, were applicable to all stages of Old Uyghur (2021: 73-76). In the book, texts were classified on the basis of 39 criteria. These criteria are divided into 


\section{ग(৫)}

groups according to orthographic features, phonological, morphophonological and morphological features, the presence of Mongolian loanwords and the external structures of the texts.

The criteria related to orthography, consist of seven title as; extra and unnecessary spelling of aleph in medial of the words, separate spelling of in medial of the words, the spelling of $/ \check{s} /$ and $/ \mathrm{n} /$, irregularities between the spellings of $/ \mathrm{d} /$ and $/ \mathrm{t} /$, also $/ \mathrm{s} /$ and $/ \mathrm{z} /$ and degemination of consonants. of these, the criteria of the spelling of $/ \mathrm{n} /$ consonant and consonant degemination were applied for the first time to date the texts in this study by Ağca.

There are ten phonological criteria: the situation of connecting vowel /A/, vowel epenthesis, labialisation, the consonant palatal /n/, alternation between /y/ /g/, metathesis, the situations of medial /d/ and /g/, the verbs qurtgarand yarligqa-. Among these, the rounding of the unrounded vowels near the labials, the alternation of $/ \mathrm{y} / \sim / \mathrm{g} /$ and the shapes of the verb qurtgar-are the criteria used for the dating of the texts for the first time in this study.

In the study, there are six criteria among the morphophonological criteria which are connecting vowel of instrumental case suffix, connecting vowel of causative suffix $\{-(\mathrm{X}) \mathrm{t}-\}$, relative suffix after nouns ending with a consonant, aorist suffix after verbs ending with vowel, the situation of the gerundium and aorist suffixes after the suffixes which ends with the sounds $/ \mathrm{k} /$ and $/ \mathrm{r} /$, and lastly the gerundium and aorist suffixes of the verbs which ends with the suffix $\{-(\mathrm{X}) \mathrm{t}-\}$. The situation of the genitive after nouns ending with a consonant was previously discussed by Gabain and Zieme as a dialectical feature of old Uyghur texts. According to this view, after the words ending with vowels in Manichaean texts, just like in Köktürk texts, this suffix is $\{+(\mathrm{X}) \eta\}$ and this is a characteristic of $/ \mathrm{n} /$ dialect. But in $/ \mathrm{y} /$ dialect, it is $\{+\mathrm{n}(\mathrm{X}) \mathrm{y}\}$ after words ending with both vowels and consonants. For the first time in Ağca's work, this language feature is taken into consideration not dialectically, but as a criterion for dating the texts.

The criteria for morphology are discussed under fourteen subtitles: accusative after the nouns in nominative case, accusative after the nouns which have possessive suffix, ablative, directive case of nouns, prepositions governing the accusative case of the nouns, dative case of the demonstrative pronouns, present participle suffixes $\{-(\mathrm{X}) \mathrm{glI}\} \sim\{-(\mathrm{X}) \mathrm{gmA}\}$, the negative forms of the past 
participle suffixes, gerundium suffix $\{-(\mathrm{X}) \mathrm{pAn}(\mathrm{In})\}$, the gerundium and aorist suffixes of the verbs al- and bil-, the situation of the conditional suffix, $\{-\mathrm{gU}\}$ ol $\{$-gUl\}, the variants of the preposition birlä and the last one is the inter-decimal number system. The presence of the directive and the state of the participle suffixes $\{-g l I\}$ and $\{-g m A\}$ are also used as criteria for the dating of the texts for the first time in this work. In addition to these, it has been stated that the use of the suffix $\{-y U k\}$ in different functions and the existence of the preposition $m A$ are criteria that may allow to the chronological classification of the texts (A $\breve{g} c a$ 2021: 78).

Mongolian loanwords in Old Uyghur texts are also treated as an important criterion for dating. According to this, the texts in which Mongolian loans seen intensively, begin to be seen with the Mongolian domination from the 13th century. The last criteria used in the dating of the texts are the features that are related to the external structures of the works such as paper, binding, reed, pen, brush, block-printing technique and font type. In addition, the source language from which the texts were translated can also give clues about the date of the texts.

After this section, in which the criteria used for the dating of old Uyghur texts in the study are discussed in detail, the old Uyghur texts are grouped into eight groups within the framework of these criteria in Chapter 3. In the last section, the texts were classified chronologically by making predictions about the centuries to which these eight groups belong. According to this, the writing date of the first group Uighur texts is close to the Köktürk inscriptions. Most of these texts, which are dated to the second half of the 8th century, are written in the Manichaean environment. In the study, the II. Group texts are dated to the middle of the 9th century at the latest. Texts in group III are located between the end of the 9th century and the first half of the 10th century. The jataka of Kalyannamkara Pāpamkara, which is the earliest dated text of the group IV, is in the second half of the 10th century, while the Hami version of Maytrisimit, which is one of the latest dated texts of the same group, was copied in 1037. Daśakarmapathāvadānamālā, which is estimated to be one of the latest texts of this group, is dated to the second half of the 11th century. It is seen that the language became more standardized in the texts belonging to the V. group placed in the late 11th century and the 12th century. The texts in the VI. group are dated to 


\section{J(e)}

the 13th century, the group VII texts are dated between the late 13th and early 14th centuries, and the latest texts belonging to the group VIII are dated to the second half of the 14th century (Ağca 2021: 403-440).

The dialects of old Turkic and the dating of old Uyghur texts are so complex but as well as so essential subject matters for Turcology studies. The presentation of this doctoral study, which fills an important gap in Turcology studies in Turkey, as a book, and its renewing on this occasion, made us, the researchers, very happy. There is no doubt that with the translation of this comprehensive and meticulous study into English, it will make important contributions to Turkology studies in the world. I hope this happens in near time.

\section{References}

Ağca, F. (2006). Eski Uygur Türkçesiyle Yazılmış Eserlerin Ses ve Şekil Özelliklerine Göre Tarihlendirilmesi. Hacettepe Üniversitesi, Sosyal Bilimler Enstitüsü, Ankara (Published PhD Thesis).

Ağca, F. (2021). Dillik Ölçütlere Göre Eski Uygurca Metinlerin Tarihlendirilmesi. Türk Dil Kurumu Yayınları.

Erdal, M. (1979). The Chronological Classification of Old Turkish Texts. Central Asiatic Journal. 3(23), 151-175.

Tekin, T. (1994). Gerhard Doerfer, Versuch einer linguistischen Daiterung älterer osttürkischer Texte, Harrassowitz Verlag, Turcologia: Band 14, Wiesbaden 1993, 255 s. Türk Dilleri Araştırmaları. 4, pp. 183-190. (Review) 